\title{
Localization of a Pyrroloquinoline Quinone Biosynthesis Gene Near the Methanol Dehydrogenase Structural Gene in Methylobacterium organophilum DSM 760
}

\author{
By P. MAZODIER, $\dagger$ F. BIVILlE, E. TURLIN AND F. GASSER* \\ Unité de Régulation de l'Expression Génétique, Département de Biochimie et Génétique \\ Moléculaire, Institut Pasteur, 28 rue du Dr Roux, F-75724 Paris Cedex 15, France
}

(Received 29 March 1988; revised 13 May 1988)

\begin{abstract}
A partial Sau3AI genomic bank of Methylobacterium organophilum DSM 760 was constructed in the cosmid pSUP106 and mox $F$, the structural gene for methanol dehydrogenase, was isolated. In $M$. organophilum, pSUP106 behaves as a suicide plasmid. This property was used to insert $\mathrm{Tn} 5$ into the bacterial chromosome, in the vicinity of $\operatorname{mox} F$, by marker exchange. Mobilization of the Tn5-labelled chromosomal region by a broad-host-range plasmid, pJB3J1 (an R68-45 derivative), allowed the selection of several large $\mathbf{R}^{\prime}$ hybrid plasmids in Escherichia coli $\mathrm{HB} 101$. Most of them were able to complement both mutants of the moxF region and mutant MTM1, the first mutant of the pyrroloquinoline quinone (PQQ) biosynthesis pathway in $M$. organophilum. The gene involved, $p q q A$, was subcloned and localized.
\end{abstract}

\section{INTRODUCTION}

Methanol dehydrogenase (MDH), which catalyses the oxidation of methanol to formaldehyde, is a key enzyme in methylotrophic bacteria utilizing methanol, either as a primary substrate or after methane oxidation. Methanol dehydrogenase is a quinoprotein, an enzyme with pyrroloquinoline quinone (PQQ) as the prosthetic group. Other quinoproteins include bacterial enzymes such as glucose dehydrogenase from Acinetobacter calcoaceticus (Duine et al., 1979), alcohol dehydrogenase from Pseudomonas aeruginosa (Groen et al., 1984) and methylamine dehydrogenase from methylotrophic bacteria (Van der Meer et al., 1987). PQQdependent enzymes have also been found in mammals, e.g. the amine oxidase from bovine serum (Lobenstein-Verbeek et al., 1984) or the lysyl oxidase from human placenta (Van der Meer \& Duine, 1986). Information about PQQ and quinoproteins has recently been reviewed (Duine et al., 1986).

The PQQ-dependent MDH of methylotrophs transfers electrons at the level of cytochrome $c$ (Anthony, 1982). In Methylobacterium sp. AM1, an organism closely related to Methylobacterium organophilum, two cytochromes $c$ have been described (O'Keefe \& Anthony, 1980): cytochrome $c_{\mathrm{L}}$, with a low isoelectric point (pI 4.2$)$ and a high molecular mass $(20.9 \mathrm{kDa})$, and cytochrome $c_{\mathrm{H}}$, with a high $\mathrm{pI}(8 \cdot 8)$ and a low molecular mass $(11 \mathrm{kDa})$. In $M$. organophilum DSM 760 we have detected a similar pattern. Purification and details of the properties of cytochromes $c_{\mathrm{L}}$ and $c_{\mathrm{H}}$ of $M$. organophilum will be reported elsewhere.

The structure of PQQ has been elucidated (Salisbury et al., 1979; Duine et al., 1980) but its biosynthetic pathway is not yet known. Recent genetic studies in $A$. calcoaceticus (Goosen et al., 1987) have shown that at least four different genes are involved in PQQ biosynthesis. There has so far been no such study in methylotrophic bacteria.

† Present address: Unité de Génie Microbiologique, Département des Biotechnologies, Institut Pasteur.

Abbreviations: $\mathrm{MDH}$, methanol dehydrogenase; PQQ, pyrroloquinoline quinone. 
In $M$. organophilum strain XX, three regions of the genome containing several genes have been reported to be involved in the expression of an active MDH (Allen \& Hanson, 1985), but the actual MDH structural gene was not located and possible defects in PQQ biosynthesis were not considered. The MDH structural gene from Paracoccus denitrificans has been cloned and its nucleotide sequence determined (Harms et al., 1987). It corresponds to the mox $F$ gene of Methylobacterium sp. AM1 described by Nunn \& Lidstrom (1986). These authors isolated 26 mutants defective in methanol oxidation which could be classified with a genomic clone bank into 10 groups by complementation analysis (mox genes $A$ to $H$ ). However, none of the mox mutants were involved in PQQ biosynthesis. In this paper, we report the isolation of the first PQQ mutant of $M$. organophilum and the localization of the gene involved, $p q q A$, next to the $\mathrm{MDH}$ structural gene mox $F$. The physiological behaviour of the PQQ mutant has already been reported (Biville et al., 1988).

\section{METHODS}

Bacterial strains, phage and plasmids. These are listed in Table 1. Relevant characteristics of plasmids are shown in Fig. 1.

Media and growth conditions. M. organophilum was grown on minimal medium (MacLennan et al., 1971) containing $0.5 \%(\mathrm{v} / \mathrm{v})$ methanol or $0.2 \%(\mathrm{w} / \mathrm{v})$ sodium succinate. LB medium (Miller, 1972) was used for Escherichia coli strains. Antibiotics, when added, were used at a final concentration of $\left(\mu \mathrm{g} \mathrm{ml}^{-1}\right)$ : kanamycin 25 , ampicillin 100, rifampicin 20, tetracycline 10 , chloramphenicol 25 . PQQ, kindly provided by J. A. Duine (Delft University of Technology, The Netherlands), was used in aqueous solution after filter-sterilization. For growth of mutant MTM1, methanol medium was supplemented with PQQ (1 $\mu \mathrm{M}$ final concentration).

Biochemical techniques. For preparation of crude extracts, bacterial cells were suspended in 20 mM-potassium phosphate buffer $\mathrm{pH} 7.0$ and passed twice through a French pressure cell at $110 \mathrm{MPa}$. After centrifugation for $30 \mathrm{~min}$ at $38000 \mathrm{~g}$, the supernatant was used immediately for assays or frozen at $-20^{\circ} \mathrm{C}$. MDH was assayed according to Anthony \& Zatman (1967) with $3 \mathrm{~mm}-\mathrm{KCN}$ added to the cuvette. Specific activity was expressed as $\mu \mathrm{mol}$ dichlorophenolindophenol reduced $\mathrm{min}^{-1}$ (mg protein) ${ }^{-1}$. PQQ was detected in crude extracts with the apoalcohol dehydrogenase from Pseudomonas testosteroni (Groen et al., 1986) using a procedure described by Biville $e t$ al. (1988).

Electrophoresis in $10 \%(\mathrm{w} / \mathrm{v})$ polyacrylamide gels was done according to the method of Laemmli (1970). After electrophoresis, proteins were stained with Coomassie blue R250 (Janvier \& Gasser, 1987) and soluble cytochromes were revealed with $3,5,3^{\prime}, 5^{\prime}$-tetramethylbenzidine according to Thomas et al. (1976).
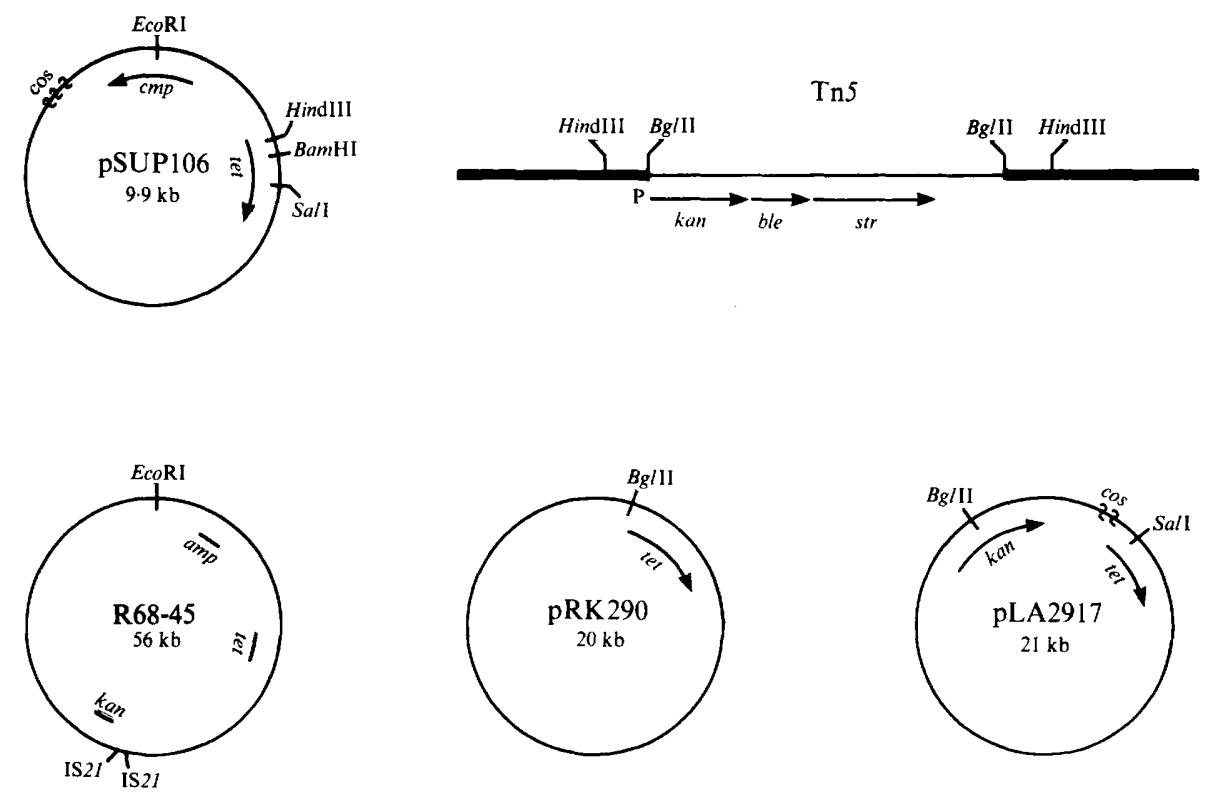

Fig. 1. Relevant characteristics of the main plasmids and transposon used in this work. 
Table 1. Bacterial strains, phage and plasmids

\begin{tabular}{|c|c|c|}
\hline Bacterial strains & Relevant characteristics & Source or reference \\
\hline Escherichia coli & hsdS20 $\left(\mathrm{r}_{\overline{\mathrm{B}}}^{-} \mathrm{m}_{\mathrm{B}}^{-}\right)$recAB proA2 & $\begin{array}{l}\text { Boyer \& Roulland- } \\
\text { Dussoix (1969) }\end{array}$ \\
\hline S17-1 & $\begin{array}{l}\text { Rec-, contains an RP4 derivative integrated in the chromosome } \\
\text { providing tra functions used in this work for transfer of } \\
\text { plasmids pSUP106, pRK290 and pLA2917 }\end{array}$ & Simon et al. (1983) \\
\hline S17-1 Rif ${ }^{r}$ & Spontaneous rifampicin-resistant derivative of $\$ 17-1$ & This work \\
\hline S17-1::Tn5 & $\begin{array}{l}\text { Insertion of Tn5 into the chromosome was achieved after } \\
\text { infection with phage } \lambda 467\end{array}$ & This work \\
\hline \multicolumn{3}{|c|}{ Methylobacterium organophilum } \\
\hline DSM760 & Wild-type strain & $\begin{array}{l}\text { Deutsche Sammlung von } \\
\text { Mikroorganismen }\end{array}$ \\
\hline \multicolumn{3}{|l|}{ EMS mutants } \\
\hline 21111 & $\mathrm{MDH}^{-}(\operatorname{mox} F)$ & This work \\
\hline MTM1 & $\mathrm{PQQ}^{-}(p q q A)$ & This work \\
\hline \multicolumn{3}{|c|}{ Tn5 insertion mutants } \\
\hline MD4 & Methanol- Cyt. $c_{\mathrm{L}}^{+}$ & This work \\
\hline MD5 & Methanol ${ }^{+}$Cyt. $c_{\mathrm{L}}^{+}$ & This work \\
\hline MD14 & Methanol- Cyt. $c_{\mathrm{L}}^{-}$ & This work \\
\hline \multicolumn{3}{|c|}{$\mathrm{Kan}^{\mathrm{r}}$ cartridge insertions } \\
\hline MDQ1 & $\mathrm{PQQ}^{+}$; insertion near $p q q A$ & This work \\
\hline MDQ2 & $\mathrm{PQQ}^{-} ;$insertion in $p q q A$ & This work \\
\hline \multicolumn{3}{|l|}{ Phage } \\
\hline$\lambda 467$ & $\begin{array}{l}\text { b221 cI857 rex:: } \operatorname{Tn} 5 \text { O29 P80; a replication-deficient, } \\
\text { integrationless phage used to deliver } \operatorname{Tn} 5 \text { into } \$ 17-1\end{array}$ & Kleckner et al. (1977) \\
\hline \multicolumn{3}{|l|}{ Plasmids } \\
\hline pSUP106 & $\begin{array}{l}\text { Conjugative cosmid using RSF1010 origin of replication; } \\
\text { Cmp }^{r} T^{r} t^{r}\end{array}$ & Priefer et al. (1985) \\
\hline pPM107 & $\begin{array}{l}\text { A pSUP106 derivative with substitution of the HindIII-BamHI } \\
\text { fragment of tet by the HindIII-BglII fragment of Tn } 5 \text {; } \\
\text { Cmpr }^{r} \text { Kan }^{r} B \text { Be }^{r}\end{array}$ & This work \\
\hline pPM111 & $\begin{array}{l}\text { A pBR322 derivative containing the whole central region of } \operatorname{Tn} 5 \\
\text { and the kan promoter }\end{array}$ & Mazodier et al. (1983) \\
\hline $\begin{array}{l}\text { pRK290 } \\
\text { pLA2917 }\end{array}$ & $\begin{array}{l}\text { IncPl, Tetr cloning vector with a single } B g l \mathrm{II} \text { cloning site } \\
\text { IncP, Tetr } \mathrm{Kan}^{r} \text {. A pRK290 derivative with a single } B g l \mathrm{II} \text { site } \\
\text { affecting } \mathrm{Kan}^{\mathrm{r}} \text { expression }\end{array}$ & $\begin{array}{l}\text { Ditta et al. }(1980) \\
\text { Allen \& Hanson (1985) }\end{array}$ \\
\hline pMO340 & $17 \mathrm{~kb}$ of $M$. organophilum mox $F$ region cloned in pSUP106 & This work \\
\hline pMO344 & $8 \mathrm{~kb}$ of $\operatorname{moxF}$ region cloned in pRK 290 in one orientation & This work \\
\hline R68-45 & IncP1, $\operatorname{Kan}^{r} \operatorname{Tet}^{r} A m p^{r}$ with chromosome-mobilizing ability & Haas \& Holloway (1976) \\
\hline pJB3JI & A kanamycin-sensitive derivative of $\mathbf{R} 68-45$ & $\begin{array}{l}\text { Given by J. Beringer, } \\
\text { University of Bristol, } \\
\text { UK }\end{array}$ \\
\hline $\begin{array}{l}\mathbf{R}^{\prime} 51 \text { to } \mathbf{R}^{\prime} 56 \\
\mathbf{R}^{\prime} 14\end{array}$ & $\begin{array}{l}\text { pJB3J1 derivatives containing DNA from } M \text {. organophilum } \\
\text { with various } T n S \text { insertions }\end{array}$ & This work \\
\hline pUC4K & $\begin{array}{l}\text { A plasmid containing a } 1400 \text { bp DNA fragment encoding } \\
\text { kanamycin resistance, with BamHI and SalI sites at each end } \\
\text { to make an adaptable gene cartridge }\end{array}$ & $\begin{array}{l}\text { Pharmacia (cat. no. } \\
\text { 27-4987-01) }\end{array}$ \\
\hline pMO500 & $6 \mathrm{~kb}$ of $M$. organophilum pqqA region cloned in pLA2917 & This work \\
\hline pMO512 & $2.5 \mathrm{~kb}$ of $p q q A$ region cloned in pSUP106 & This work \\
\hline pMO5121 & Same as pMOS12, with $\mathrm{Kan}^{\mathrm{r}}$ cartridge near $p q q A$ & This work \\
\hline pMO5122 & Same as pMO512, with $\mathrm{Kan}^{r}$ cartridge in $p q q A$ & This work \\
\hline & $\begin{array}{l}\text { A pEX2 derivative containing mdh, the structural gene of MDH } \\
\text { from Paracoccus denitrificans }\end{array}$ & Harms et al. (1987) \\
\hline
\end{tabular}

Purification of $M D H$. The purification was carried out at $0-4^{\circ} \mathrm{C}$. Methanol (10 mM) was added as a stabilizer in all the buffers and solutions. Crude extract obtained from $15 \mathrm{~g}$ wet weight of bacterial cells was slowly acidified with $10 \%(\mathrm{v} / \mathrm{v})$ acetic acid to $\mathrm{pH} 5 \cdot 5$. The precipitate was removed by centrifugation for $30 \mathrm{~min}$ at $20000 \mathrm{~g}$. Protamine sulphate was slowly added with stirring to a final concentration of $0.3 \%$. The resulting precipitate was discarded after centrifugation for $30 \mathrm{~min}$ at $20000 \mathrm{~g}$. The supernatant was concentrated in an Amicon cell with a 
YM30 membrane (molecular mass cut-off $30000 \mathrm{Da}$ ), diluted with ten volumes of $10 \mathrm{mM}$-acetate buffer $\mathrm{pH} 5.5$ and concentrated again. This operation was repeated twice. The extract was applied to a column $(20 \times 2.5 \mathrm{~cm})$ of CM-trisacryl (LKB-IBF), equilibrated with $10 \mathrm{mM}$-acetate $\mathrm{pH} 5 \cdot 5$. MDH was eluted with a linear gradient $(0-150 \mathrm{mM})$ of $\mathrm{NaCl}$ in $10 \mathrm{~mm}$-acetate buffer. The most active fractions were pooled, concentrated and applied to a Sephadex G200 column $(1.5 \times 60 \mathrm{~cm})$. The active peak presented a single protein band after polyacrylamide gel electrophoresis (PAGE). The pure enzyme had a specific activity of 2.6 units. The purification procedure gave a $38 \%$ yield with a 12 -fold purification of the enzyme. The enzyme was stored at $-20^{\circ} \mathrm{C}$ in $20 \mathrm{~mm}$-phosphate buffer $\mathrm{pH} 7 \cdot 0$.

Immunological techniques. Antiserum was prepared in three-month-old virgin female Bouscat rabbits. Each animal received an intradermal injection of $30 \mu \mathrm{g}$ pure $\mathrm{MDH}$ in $0.25 \mathrm{ml}$ saline $\mathrm{pH} 7.0$ emulsified in the same volume of incomplete Freund's adjuvant (Difco). One month later the rabbits were boosted with the same emulsion and bled $10 \mathrm{~d}$ later. Immunodiffusion experiments were done by the method of Ouchterlony as previously reported (Hontebeyrie \& Gasser, 1975).

Molecular biology techniques. DNA isolation, endonuclease digestion, alkaline phosphatase treatment, ligation, DNA transformation, nick-translation and nitrocellulose filter hybridization were done essentially as described by Maniatis et al. (1982). Purification of $M$. organophilum total DNA was achieved essentially by the method of Marmur (1961).

Mutagenesis and mutant selection. Two millilitres of a culture of wild-type $M$. organophilum DSM 760 in methanol medium were treated during the early exponential phase (optical density, $\left.\mathrm{OD}_{600}=0.6\right)$ with $0.01 \%(\mathrm{v} / \mathrm{v})$ ethylmethane sulphonate (EMS). After $2 \mathrm{~h}$ incubation at $30^{\circ} \mathrm{C}$ with shaking, the culture was centrifuged and washed twice in medium $A$ without carbon source. The final pellet was resuspended in succinate minimal medium $(4 \mathrm{ml})$ and the culture incubated at $30^{\circ} \mathrm{C}$ for $24 \mathrm{~h}$. For enrichment of mutants unable to grow on methanol, washed cells of the latter culture were used to inoculate (at $\mathrm{OD}_{600}$ 0.05) methanol minimal medium (4 ml). At $\mathrm{OD}_{600} 0 \cdot 1$, penicillin $\mathrm{G}\left(2000 \mathrm{IU} \mathrm{ml}^{-1}\right)$ was added and incubation was continued for another $24 \mathrm{~h}$. The resulting culture was diluted and spread onto succinate minimal medium plates. Colonies were replica-plated onto succinate and methanol media and cells unable to grow on methanol medium were streaked for further purification.

Construction of the genomic bank. The genomic bank was constructed in the broad-host-range cosmid pSUP106, which contains a unique BamHI cloning site in the tet gene (Fig. 1). Total DNA of $M$. organophilum DSM 760 was partially digested with Sau3A, ligated in a 3:1 ratio to plasmid pSUP106 cut by BamHI and packaged in vitro. Bacteriophage $\lambda$ packaging extracts were prepared and packaging was performed as described by Hohn \& Collins (1980). The host strain $E$. coli $\mathrm{S} 17-1$ was infected and chloramphenicol-resistant, tetracycline-sensitive colonies were selected. E. coli $\mathrm{S} 17-1$ possesses plasmid-mobilization genes integrated within the chromosome and thus can be used for biparental crosses necessary to test genetic complementation of $M$. organophilum (Simon et al., 1983).

Conjugation. In the absence of phage and of a transformation system, DNA could be introduced in $M$. organophilum only by conjugation. Conditions of conjugation between $E$. coli and $M$. organophilum (and reciprocal) have been described (Mazodier et al., 1983).

Screening of the $M$. organophilum genomic bank constructed in $E$. coli was done by drop mating on minimal medium plates supplemented with $0.5 \%(\mathrm{v} / \mathrm{v})$ methanol and $0.01 \%(\mathrm{w} / \mathrm{v})$ sodium succinate. A recipient $M$. organophilum mutant was resuspended in LB medium and 25 drops were separately added to a plate; then 25 different $E$. coli $\mathrm{S} 17-1$ donor clones were patched, each to a different drop. Plates were then incubated for up to $4 \mathrm{~d}$ at $30^{\circ} \mathrm{C}$. The medium composition prevented growth of either donors or recipients but allowed the growth after complementation of the recipient mutation.

\section{RESULTS}

\section{Selection of methanol oxidation mutants and screening of the genomic library built in pSUP106}

Among $20 \mathrm{M}$. organophilum mutants unable to grow on methanol, two, 2111I and MTM1, were capable of normal growth on methylamine and consequently were not impaired in the serine pathway of formaldehyde incorporation. Their main biochemical characteristics are reported in Table 2 and Fig. 2. The mutant MTM1 can grow normally on methylamine, as in $M$. organophilum this compound is dissimilated through a methylglutamate dehydrogenase (Biville et al., 1988), which is a flavohaemoprotein enzyme (Boulton et al., 1980) rather than through methylamine dehydrogenase, a PQQ-dependent enzyme (Van der Meer et al., 1987). This latter enzyme was not detected in this organism (Biville et al., 1988), but it was present in Methylobacterium sp. AM1 (Eady \& Large, 1968).

A genomic library of 800 clones was screened by conjugation with the two mutants $2111 \mathrm{I}$ and MTM1. No complementation of the PQQ ${ }^{-}$mutant, MTM1, occurred. Complementation of mutant 2111 I was observed with four $E$. coli clones. Restriction maps of the corresponding 

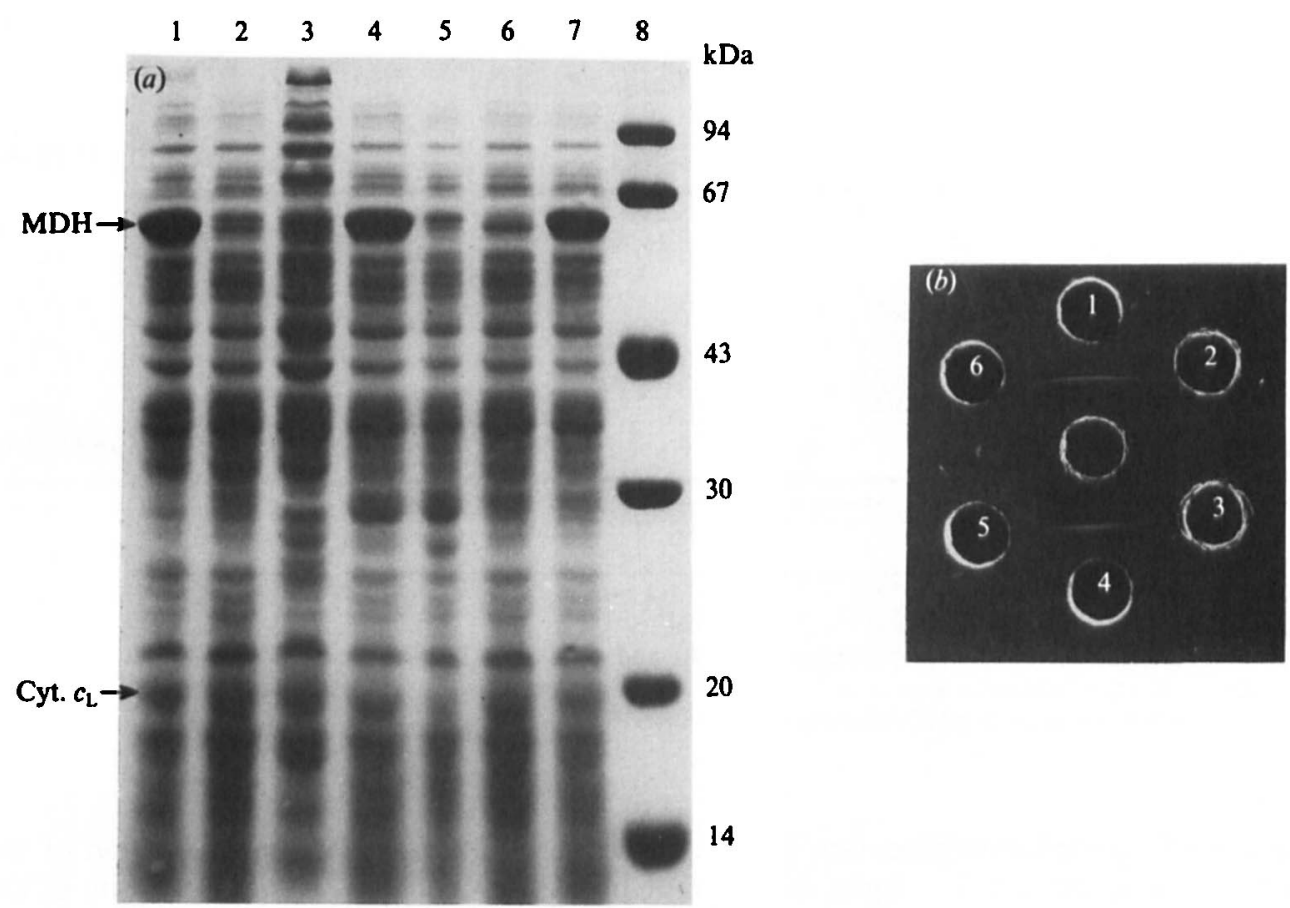

Fig. 2. (a) PAGE and $(b)$ immunoprecipitation in Ouchterlony plates of crude extracts from succinategrown cells of $M$. organophilum DSM 760 wild-type (1) and of methanol oxidation mutants MTM1 (2), 2111 (3), MD4 (4), MD14 (5), MDQ2 (6) and MDQ1 (7). Lane 8 in (a) contains molecular mass markers. The amount of protein was $75 \mu \mathrm{g}$ for each electrophoresis lane and in each well of the Ouchterlony plate. The central well received $80 \mu \mathrm{l}$ of antiserum prepared against pure MDH.

Table 2. Biochemical characteristics relevant to methanol oxidation in wild-type $M$. organophilum and in methanol oxidation mutants

\begin{tabular}{|c|c|c|c|c|c|c|c|}
\hline \multirow[b]{3}{*}{ M. organophilum strain } & \multicolumn{3}{|c|}{$\mathrm{MDH}^{*}$} & \multicolumn{2}{|c|}{ PQQ concn $*$ in: } & \multirow{2}{*}{\multicolumn{2}{|c|}{ Cytochromes $c$}} \\
\hline & \multirow[b]{2}{*}{ Activity } & \multirow[b]{2}{*}{ PAGE } & \multirow{2}{*}{$\begin{array}{l}\text { Immuno- } \\
\text { precipitation }\end{array}$} & \multirow{2}{*}{$\begin{array}{l}\text { Crude } \\
\text { extracts }\end{array}$} & \multirow{2}{*}{$\begin{array}{c}\text { Culture } \\
\text { supernatants }\end{array}$} & & \\
\hline & & & & & & $c_{\mathrm{L}}$ & $c_{\mathrm{H}}$ \\
\hline DSM 760 (wild-type) & $0 \cdot 51$ & + & + & $1 \cdot 15$ & $0 \cdot 33$ & + & + \\
\hline \multicolumn{8}{|l|}{ EMS mutants } \\
\hline 21111 & 0.02 & $+w$ & - & 0.06 & $1 \cdot 0$ & + & + \\
\hline MTM1 & 0 & $+w$ & - & 0.04 & 0 & + & + \\
\hline \multicolumn{8}{|c|}{ Chromosomal Tn5 mutants } \\
\hline MD4 & $0 \cdot 04$ & + & + & 1.04 & NT & + & + \\
\hline MD14 & 0.03 & $+w$ & $+w$ & 0.09 & $2 \cdot 0$ & - & + \\
\hline \multicolumn{8}{|c|}{ Chromosomal cartridge mutants } \\
\hline MDQ1 & $0 \cdot 54$ & + & + & 0.85 & 0.33 & + & + \\
\hline MDQ2 & 0 & $+w$ & $+w$ & $<0.02$ & 0 & + & + \\
\hline
\end{tabular}

w, Weak; NT, not tested.

* Succinate-grown cells, centrifuged in the early stationary phase.

† Units: $\mu \mathrm{mol}$ dichlorophenolindophenol reduced $\mathrm{min}^{-1}$ (mg protein) ${ }^{-1}$.

$\ddagger$ Units: nmol PQQ (mg protein ${ }^{-1}$ ) or (ml culture supernatant) ${ }^{-1}$.

plasmids showed some common features. One of them, pMO340 (Fig. 3) was kept for further studies.

The mutation in strain 21111 affects the $M D H$ structural gene

Plasmid pMO340 contains $17 \mathrm{~kb}$ of $M$. organophilum DNA. Subcloning was therefore necessary to locate the gene which could complement mutant 2111I. Plasmid pSUP106 does not 


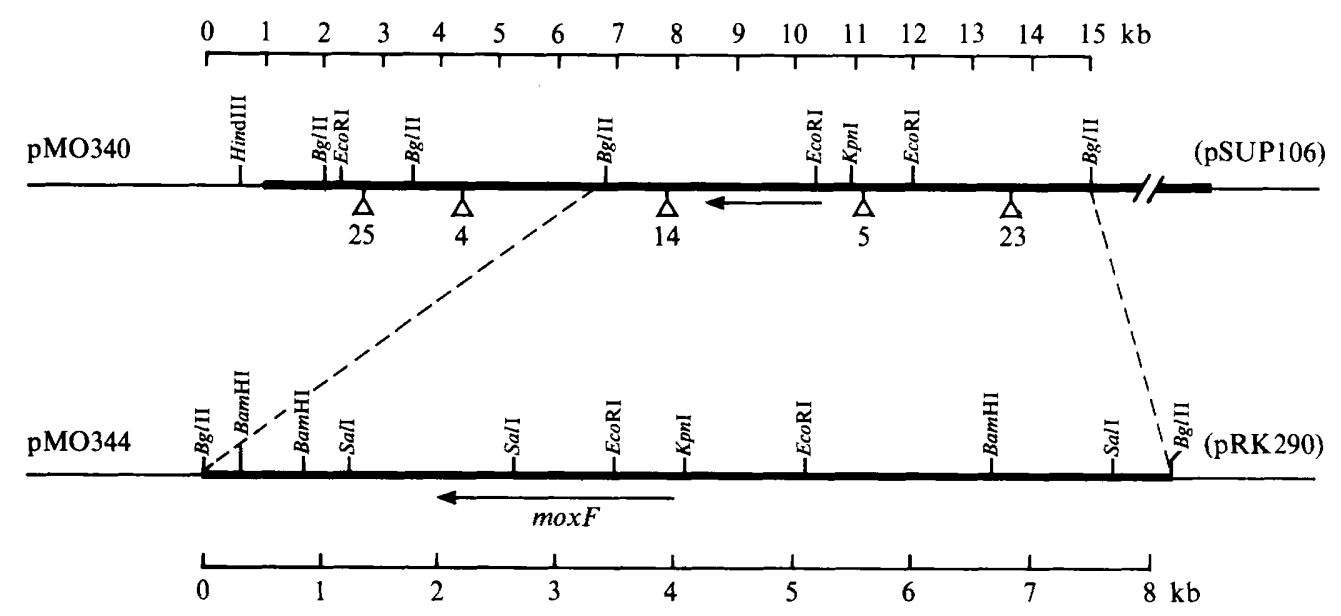

Fig. 3. Restriction maps of plasmids pMO340 and pMO344. The location and the direction of transcription of the structural gene of $M D H, \operatorname{mox} F$, were established from the data shown in Fig. 4. Numbered triangles in pMO340 indicate Tn5 insertions.

allow stable complementation (see below). In order to obtain true complementation of the mutation in strain 2111I, a $B g l \mathrm{II}$ digestion of pMO340 was cloned at the $B g l \mathrm{II}$ site of the replicative plasmid pRK290. The resulting plasmids were introduced into $E$. coli S17-1 by transformation and transferred to mutant 21111 by conjugation. Recipient selection was achieved on methanol medium containing tetracycline. Plasmid pMO344, containing an $8 \mathrm{~kb}$ fragment (Fig. 3) complemented mutant 21111 .

In order to identify the gene complementing the mutation in strain $2111 \mathrm{I}$, two fragments of pNH3, which encodes the MDH structural protein of Paracoccus denitrificans (Harms et al., 1987), were used as hybridization probes (Fig. 4). A $1.4 \mathrm{~kb}$ SalI-KpnI fragment of plasmid pMO340 showed cross-hybridization to the MDH structural gene of $P$. denitrificans. In accordance with the nomenclature of Nunn \& Lidstrom (1986) we refer to the homologous gene of $M$. organophilum as mox $F$.

\section{Behaviour of plasmid pSUP106 in M. organophilum}

The conjugative cosmid pSUP106 was designed to allow the transfer of large DNA fragments to a wide range of Gram-negative bacteria (Priefer et al., 1985). Therefore, it was a potentially good candidate to establish a possible genetic link between the MDH and PQQ genes, provided that it could easily be transferred to and from $M$. organophilum and maintained in this organism to ensure trans complementation.

pSUP106 contains resistance genes to chloramphenicol and tetracycline. M. organophilum has a high level of natural resistance to chloramphenicol and therefore this antibiotic cannot be used as a selectable marker. On the other hand, $M$. organophilum is sensitive to low concentrations of tetracycline. However, after crosses of $E$. coli S17-1(pSUP106) $\times$ M. organophilum DSM 760 no tetracycline-resistant exconjugant could be isolated on methanol medium. This might be explained by an absence of transfer of pSUP106, by the inability of this plasmid to replicate in $M$. organophilum, or by poor expression of the tet gene.

We have previously shown that the neomycin-resistance gene of $\operatorname{Tn} 5$ is highly expressed in $M$. organophilum (Mazodier et al., 1982). Therefore, the tet gene of pSUP106 was replaced by a fragment of the central region of Tn5 containing the kanamycin-resistance gene and its promoter (plasmid pPM107, Table 1). After conjugation between E. coli S17-1(pPM107) and $M$. organophilum DSM 760, selection was made on minimal medium containing methanol and kanamycin. The undiluted mating mixture led to a heavy background of pink growth of $M$. organophilum but no single colonies could be obtained when dilutions were plated. Attempts 


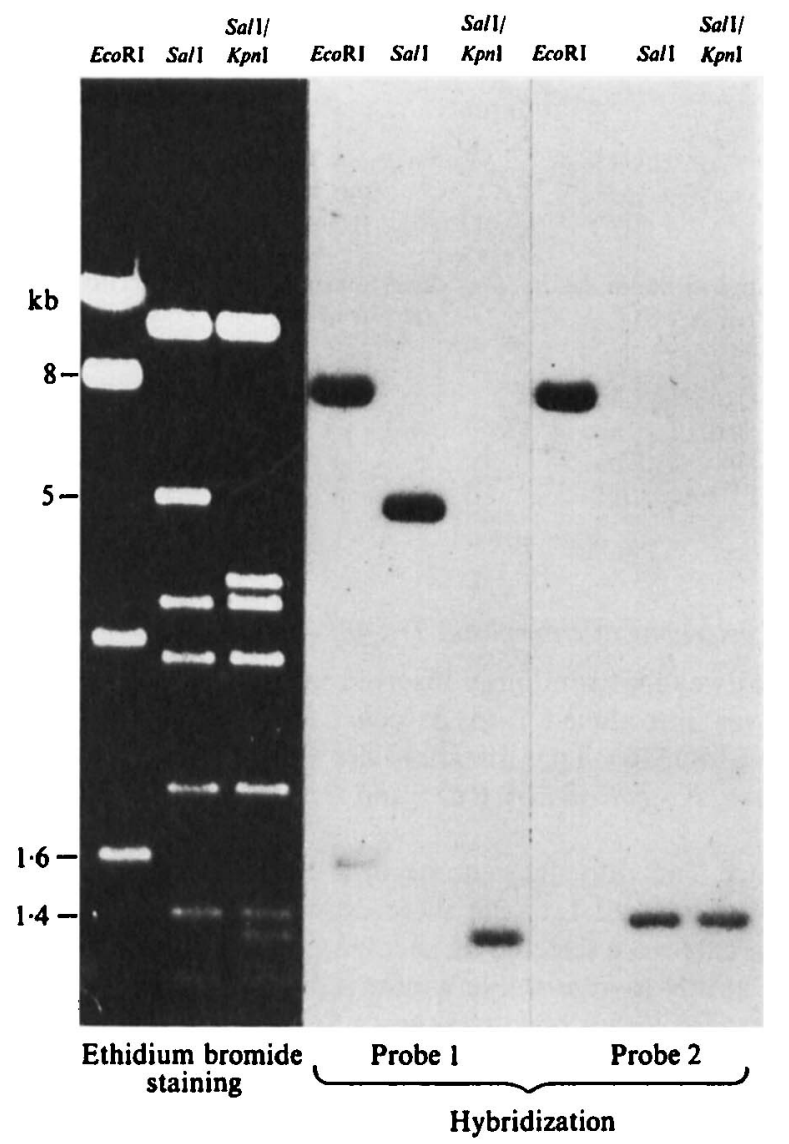

Fig. 4. Hybridization of restriction fragments of pMO340 with plasmid pNH3, which encodes the MDH structural gene from Paracoccus denitrificans (Harms et al., 1987). After digestion by EcoRI and $\mathrm{Sal}$, two fragments of pNH3 were electroeluted and used as probes: probe 1 was the $1.4 \mathrm{~kb} E c o \mathrm{RI}$ fragment which corresponds to the $5^{\prime}$ end of the MDH structural gene and probe 2 was the $0.8 \mathrm{~kb}$ EcoRI-SalI fragment of the $3^{\prime}$ end of the gene. Plasmid pMO340 was digested with EcoRI, SalI and $S a l$ I/KpnI, analysed on agarose gel (left) and hybridized with the two probes. The pattern of hybridization allowed the location of the MDH structural gene and its orientation leftward as shown in Fig. 3 to be determined.

to obtain single colonies from the background growth were not successful. To check that the background growth was the consequence of plasmid transfer and was not due to protection by the kanamycin-resistance gene present in the donor $E$. coli, the latter gene was introduced into the non-conjugative plasmid pBR322 (giving plasmid pPM111, Table 1). After crosses of E. coli S17-1(pPM111) $\times M$. organophilum DSM 760, no background growth was observed on methanol medium complemented with kanamycin.

The conclusion is that pSUP106 is probably transferred to $M$. organophilum but cannot replicate in this environment. The background growth can be explained by a high level of transfer of pSUP106 and a subsequent burst of expression of the kanamycin-resistance gene, followed by a decrease of resistance by a dilution effect at each cell division. If this hypothesis is correct, pSUP106 containing cloned $M$. organophilum DNA could be used as a suicide plasmid producing transient complementation, possibly followed by recombination between homologous cloned and chromosomal DNA, thus permitting the introduction of modifications into the genome of $M$. organophilum. This hypothesis is confirmed in the following section. 
Table 3. Specificity of partial chromosome exchange in $M$. organophilum as evidenced by growth on methanol medium of Tn5 insertion mutants after integration of pMO340 plasmids containing different Th5 insertions

\begin{tabular}{|c|c|c|}
\hline \multirow[b]{2}{*}{$\begin{array}{l}\text { Plasmid in donor strain } \\
(\text { E. coli } \mathrm{S} 17-1)\end{array}$} & \multicolumn{2}{|c|}{$\begin{array}{l}\text { Growth on methanol } \\
\text { (medium of Tn5-containing } \\
\text { recipient mutants) }\end{array}$} \\
\hline & $\begin{array}{l}\text { Insertion no. } 4 \\
\text { (strain MD4) }\end{array}$ & $\begin{array}{l}\text { Insertion no. 14 } \\
\text { (strain MD14) }\end{array}$ \\
\hline pMO340 & + & + \\
\hline pMO340::Tn5 no. 4 & - & + \\
\hline pMO340::Tn5 no. 14 & + & - \\
\hline pMO340:: Tn5 no. 5 & + & + \\
\hline pSUP106 (control) & - & - \\
\hline
\end{tabular}

\section{Directed insertions of transposon Tn5 into the $M$. organophilum genome}

The transposon $\operatorname{Tn} 5$ was first randomly inserted into various sites of the plasmid pMO340. For this, pM@340 was introduced into $E$. coli S17-1::Tn5 (Table 1) by transformation. Selection of various pMO340::Tn 5 insertion derivatives was achieved by a cross $E$. coli S17-1::Tn5(pMO340) $\times E$. coli S17-1 Rif ${ }^{r}$ and subsequent selection of $\operatorname{Rif}^{r} \mathrm{Cmp}^{\mathrm{r}} \mathrm{Kan}^{\mathrm{r}}$ exconjugants.

In order to introduce Tn 5 into the genome of $M$. organophilum, 26 clones of $E$. coli S17-1 Rif ${ }^{\mathrm{r}}(\mathrm{pMO} 340:: \operatorname{Tn} 5)$, numbered 1 to 26 , were crossed with $M$. organophilum wild-type. $M$. organophilum exconjugants were selected on succinate medium containing kanamycin. Only six donor clones had the ability to give stable kanamycin-resistant $M$. organophilum exconjugants, which appeared as large colonies on a background of microcolonies. After each cross, seven colonies of $\mathrm{Kan}^{\mathrm{r}}$ exconjugants were re-isolated and examined for methanol utilization. None of the $M$. organophilum exconjugant clones (7/7) which received $\operatorname{Tn} 5$ insertions 4 or 14 grew on methanol medium. Those which received Tn 5 insertions 5, 23 or 25 were unaffected in methanol utilization. Restriction mapping of the corresponding plasmids gave the locations of the different insertions of $\mathrm{Tn} 5$ in pMO340 (Fig. 3).

$M$. organophilum exconjugants with Tn5 insertions 4 and 14, which affected regions involved in methanol utilization, were named mutants MD4 and MD14 respectively. Their biochemical characteristics are given in Table 2 . Spontaneous reversion of these mutants to the wild-type phenotype, i.e. growth on methanol medium, occurred at a frequency of about $10^{-9}$, with simultaneous loss of kanamycin resistance.

The specificity of the insertions of $\mathrm{Tn} 5$ into the genome of $M$. organophilum was checked by crosses of mutants MD4 and MD14 with E. coli S17-1(pMO340) and S17-1(pMO340::Tn5) (numbers 4, 5 and 14). The results of these conjugations (Table 3) exclude the possibility of $\mathrm{Tn} 5$ transposition from pSUP106 to the chromosome of $M$. organophilum. A complete lack of $\operatorname{Tn} 5$ transposition in $M$. organophilum has been observed previously (Mazodier et al., 1983). The fact that the mutations in strains MD4 and MD14 can be abolished in this way suggests rather that $\operatorname{Tn} 5$ was integrated as a part of the DNA of pMO340:: $\operatorname{Tn} 5$ by a double crossing-over between homologous sequences present both in pMO340 and in the chromosome of $M$. organophilum. The fraction of pMO340 originating from pSUP106 was not integrated in the chromosome of $M$. organophilum: in 'dot-blot' analyses of the genomes of MD4, MD5 and MD14, no hybridization was observed when pSUP106 was used as a probe, but a strong signal was obtained with an internal Tn5 DNA fragment as probe (results not shown).

In another experiment the stability of Tn 5 insertion in pMO340 was checked by crosses between $E$. coli $\mathrm{S} 17-1$ (pMO340::Tn5 no. 5) and $M$. organophilum mutant 2111 , followed by selection on succinate medium containing kanamycin. Of 34 colonies obtained on succinate medium, 33 could also grow on methanol medium. This result also suggested the proximity of Tn5 insertion no. 5 and the mutation present in $2111 \mathrm{I}$. 
In conclusion, the behaviour of pSUP106 as a suicide plasmid in $M$. organophilum allows the possibility of creating insertion mutations in defined regions of the chromosome of this organism.

\section{Cloning the mox $F$ region on $R^{\prime}$ plasmids}

In an attempt to locate the mutation of strain MTM1 next to the mox $F$ region, a technique employing R' plasmids was used. Moore et al. (1983) cloned up to $200 \mathrm{~kb}$ of chromosomal DNA from Methylophilus methylotrophus in R68-45, a plasmid able to mobilize efficiently the chromosome of several Gram-negative bacteria. As a chromosome-mobilizing vector, the plasmid pJB3J1, a kanamycin-sensitive mutant of R68-45, was used to allow the use of the kanamycin resistance of Tn 5 as a chromosomal marker. $M$. organophilum mutant MD5, which has a Tn 5 insertion proximal to the mox $F$ region (Fig. 3), received pJB3J1 from $E$. coli. After selection for tetracycline-resistant exconjugants and subsequent purifications, a clone of $\boldsymbol{M}$. organophilum MD5(pJB3J1) was conjugated with $E$. coli HB101 and kanamycin-resistant $E$. coli exconjugants were selected. Six purified colonies, called HB101( $\left.R^{\prime} 51\right)$ to $H B 101\left(R^{\prime} 56\right)$ were crossed with mutants 2111I, MD4, MD14 and MTM1. All four mutants were complemented by all the $R^{\prime}$ plasmids except for one, $R^{\prime} 56$, which failed to complement mutant MTM1.

These results indicated that the piece of $M$. organophilum DNA present in these plasmids was, as expected, contiguous to Tn 5 insertion no. 5. It was larger than the insert in pMO340 because it complemented the distal mutation in MTM1. Among other $\mathbf{R}^{\prime}$ plasmids built on the same model, $R^{\prime} 14 B$, the smallest able to complement both $2111 \mathrm{I}$ and MTM1, had an insert of about $30 \mathrm{~kb}$, demonstrating that at least one PQQ biosynthesis gene is in the vicinity of the mox $F$ region. This gene was termed $p q q A$. Most of the $\mathrm{R}^{\prime}$ plasmids were very stable in $E$. coli, where they could be maintained for months.

\section{Subcloning of pqqA in pLA2917}

Plasmid pLA2917 is a derivative of pRK290, able to replicate in $M$. organophilum (Fig. 1, Table 1). Plasmid R'51 DNA was partially digested with Sau3A and ligated to pLA2917 cut by BglII. After transformation in E. coli S17-1, tetracycline-resistant, kanamycin-sensitive clones were selected. Several clones could effect complementation of the mutation in strain MTM1. Plasmid pMO500, with an insertion of $6 \mathrm{~kb}$ of $M$. organophilum DNA, was isolated from one of these clones (Fig. 5).

\section{Directed mutagenesis of the chromosomal pqqA region}

MTM1 was isolated after mutagenesis with EMS, a mutagen known to produce multiple, tightly grouped mutations. To exclude any additional undetected PQQ mutations which might be present in the chromosome of strain MTM1 we decided to replace the pqqA chromosomal region of wild-type $M$. organophilum by an homologous plasmidic region containing an insertion with a resistance marker, using the procedure of gene substitution by double crossing-over described for pMO340::Tn5 in this work.

Different restriction fragments of pMO500 were subcloned in pSUP106 to locate more precisely the gene $p q q A$ involved in complementation of the mutation in strain MTM1. The $p q q A$ gene was located in the $2.5 \mathrm{~kb} \mathrm{BglII}-X h o \mathrm{I}$ DNA fragment of plasmid pMO512 (Fig. 5).

The $\mathrm{Kan}^{\mathrm{r}}$ cartridge of pUC4K (Table 1) was cloned into two different restriction sites of pMO512, BamHI and SalI, yielding plasmids pMO5121 and pMO5122 respectively (Fig. 5). After transformation in $E$. coli $\mathrm{S} 17-1$ and subsequent transfer in $M$. organophilum, exconjugants were selected for kanamycin resistance and tested for growth on methanol medium. The Kan ${ }^{t}$ exconjugant MDQ1, selected after the cross using pMO5121, was not affected in growth on methanol. With pMO5122 the kanamycin-resistant exconjugant, MDQ2, was unable to synthesize PQQ (Table 2) or grow on methanol medium without added PQQ. MDQ2 could be complemented by pMO500. Accordingly $p q q A$ was located in the $1.5 \mathrm{~kb} B g l \mathrm{II}-\mathrm{BamHI}$ fragment. The biochemical characteristics of strains MDQ1 and MDQ2 are given in Table 2. 

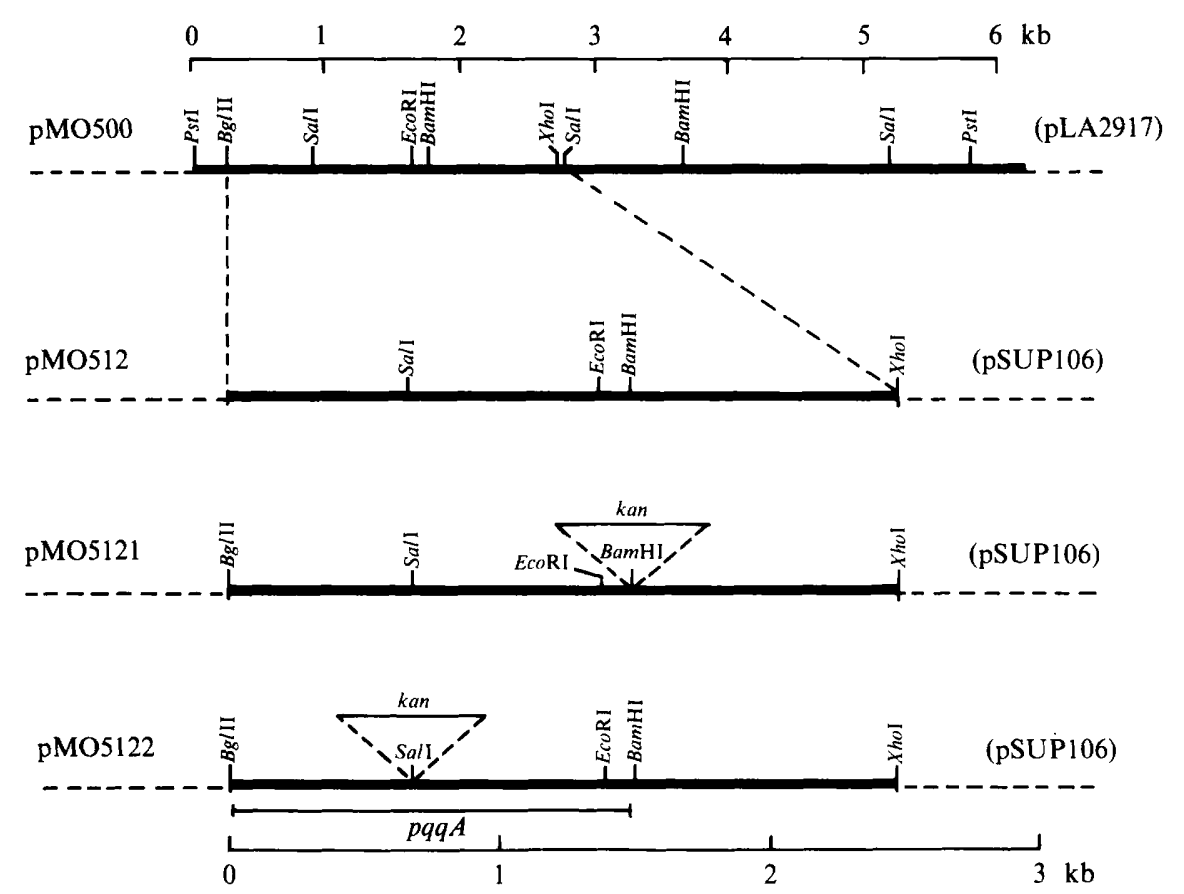

Fig. 5. Restriction map of plasmids containing DNA of the pqqA region from $M$. organophilum. Plasmid pMO512 complemented the mutation MTM1. The activity of the pqqA gene was affected by the $\mathrm{Kan}^{\mathrm{r}}$ cartridge inserted at the SalI site but not by an insertion at the BamHI site.

\section{DISCUSSION}

Plasmid pSUP106 was designed on the basis of conventional E. coli vectors and modified to include mobilization and broad-host-range replication functions of the IncQ plasmid RSF1010 (Priefer et al., 1985). Stable replication of pSUP106 has been obtained in various Gram-negative genera such as Rhizobium, Agrobacterium and Pseudomonas.

We have observed the inability of pSUP106 and of its cosmid hybrids to replicate in $M$. organophilum. This property made it possible to use pSUP106 hybrids as suicide vectors and therefore, after appropriate $\operatorname{Tn} 5$ insertions, to proceed to localized mutagenesis in the chromosome of $\boldsymbol{M}$. organophilum. Thus all possible multiple mutations so frequently found after chemical mutagenesis were excluded. Moreover, DNA exchange between homologous chromosomal and plasmidic regions adjacent to a $\mathrm{Tn} 5$ insertion allowed the modification of the genome, an important feature for strain improvement. For example, the wild-type MDH structural gene might be replaced by an in vitro-modified gene cloned in pMO340::Tn 5 no. 5 , simply by selecting kanamycin-resistant colonies of cells containing this $\mathrm{Tn} 5$ insertion, which is close to the MDH structural gene.

Finally, taking advantage of the introduction of precisely localized chromosomal markers, prime plasmids were constructed including large fragments of chromosomal DNA from $M$. organophilum. With these prime plasmids, the $p q q A$ gene has been located in the vicinity $(\leqslant 30 \mathrm{~kb})$ of the $\operatorname{mox} F$ region.

The pqqA gene was not found in the gene library built in pSUP106. This gene was subcloned from the plasmid $\mathrm{R}^{\prime} 51$ and labelled with two kanamycin resistance gene insertions, one inside $p q q A$ (strain MDQ2) and the other next to $p q q A$ (MDQ1) (Fig. 5). This will allow further easy cloning of the pqqA region and of the DNA fragment between $p q q A$ and moxF. The mutagenesis by Tn 5 of R'51 DNA fragments inserted in pSUP106 and subsequent transfer to the $M$. organophilum chromosome will permit further localized mutagenesis of this region of the genome. Indeed, several other $p q q$ genes remain to be found. At least four genes have been 
shown to be involved in PQQ biosynthesis in Acinetobacter calcoaceticus (Goosen et al., 1987) and they have to be located in $M$. organophilum.

Allen \& Hanson (1985) reported a similar location of the defect of our mutant $2111 \mathrm{I}$ to that found in this work and we have shown that this mutation affects the structural gene of MDH $(\operatorname{mox} F)$. The Tn5 insertion no. 14 present in mutant MD14 was located in the close vicinity of $\operatorname{mox} F$. This insertion affects the synthesis of cytochrome $c_{\mathrm{L}}$. A similar clustering of genes is also present in Methylobacterium sp. AM1 (moxF and moxG, Nunn \& Lidstrom, 1986), even though these two Methylobacterium species share only $29 \%$ DNA homology (Hood et al., 1987).

The results reported in Table 2 show that the amount of PQQ in crude extracts is very low when the apo-MDH, i.e. the product of the structural gene, is not synthesized. However, under these conditions, when the synthesis of PQQ is unaffected, an excess of this compound was found in the culture supernatant, as compared with the wild-type. This observation confirmed that free PQQ cannot accumulate in the cell, as has already been observed (Biville et al., 1988). On the other hand, a very low amount of apo-MDH was present in crude extracts of mutants MTM1 and MDQ2, unable to synthesize PQQ (Table 2). It is not possible to decide whether PQQ has a positive effect on the biosynthesis of apo-MDH or a stabilizing effect on an unstable apoenzyme. The latter hypothesis is more probable since generally prosthetic groups are not considered as inducers of their own apoenzymes.

The mutation of strain MD14 was located in a region apparently coding for cytochrome $c_{\mathrm{L}}$ synthesis and downstream of the gene mox $F$ encoding apo-MDH. Notwithstanding this location the amount of apo-MDH detected in extracts of MD14 was very low (Fig. 2) and, as already discussed, PQQ was detected mainly in the culture supernatant (Table 2). This observation suggests that the assembly of holo-MDH of $M$. organophilum cannot be carried out correctly in the absence of cytochrome $c_{\mathrm{L}}$. At present, the observed phenotype of mutant MD4 is not clearly explicable. Although MDH and cytochrome $c_{\mathrm{L}}$ were apparently normal, in accordance with the location of the mutation, MDH activity was practically absent in crude extracts. A possible hypothesis is the presence of a positive effector associated with $\mathrm{MDH}$ activity, which might be encoded in this region of the genome.

We thank Nellie Harms for providing plasmid pNH3, J. A. Duine for his gift of PQQ, and Paul Dyson for critical reading of the manuscript.

\section{REFERENCES}

Allen, L. N. \& Hanson, R. S. (1985). Construction of broad host range cloning vectors: identification of genes necessary for growth of Methylobacterium organophilum on methanol. Journal of Bacteriology 161, 955-962.

ANTHONY, C. (1982). The Biochemistry of Methylotrophs, pp. 229-232. London: Academic Press.

ANTHony, C. \& Zatman, L. J. (1967). The microbial oxidation of methanol. The prosthetic group of alcohol dehydrogenase of Pseudomonas sp. M27: a new oxidoreductase prosthetic group. Biochemical Journal 104, 960-969.

Biville, F., Mazodier, P., Gasser, F., Van Kleef, M. A. G. \& Duine, J. A. (1988). Physiological properties of a PQQ mutant of Methylobacterium organophilum. FEMS Microbiology Letters 52, 53-58.

Boulton, C. A., Haywood, G. W. \& LaRge, P. J. (1980). $\mathrm{N}$-Methylglutamate dehydrogenase, a flavohaemoprotein purified from a new pink trimethylamine-utilizing bacterium. Journal of General Microbiology 117, 293-304.

BOYER, H. W. \& Roulland-Dussolx, D. (1969). A complementation analysis of the restriction and modification of DNA in Escherichia coli. Journal of Molecular Biology 41, 459-472.

Ditta, G., Stanfield, S., Corbin, D. \& Helinski, D. (1980). Broad host range DNA cloning system for gram-negative bacteria : construction of a gene bank in Rhizobium meliloti. Proceedings of the National Academy of Sciences of the United States of America 77, 7347-7351.

Duine, J. A., Frank, J., JR \& Van Zeeland, K. (1979). Glucose dehydrogenase from Acinetobacter calcoaceticus: a quinoprotein. FEBS Letters 108, 443-446.

Duine, J. A., Frank, J., JR \& Verwiel, P. E. J. (1980). Structure and activity of the prosthetic group of methanol dehydrogenase. European Journal of Biochemistry 108, 186-192.

Duine, J. A., Frank, J., JzN \& Jongejan, J. A. (1986). Enzymology of quinoproteins. Advances in Enzymo$\log y$ 58, 169-211.

EADY, R. R. \& LARGE, P. J. (1968). Purification and properties of an amine dehydrogenase from Pseudomonas AM1 and its role in growth on methylamine. Biochemical Journal 106, 245-255. 
Goosen, N., Vermaas, D. A. M. \& Van de Putte, P. (1987). Cloning of the genes involved in synthesis of coenzyme pyrroloquinoline quinone from Acinetobacter calcoaceticus. Journal of Bacteriology 169, 303307.

Groen, B., Frank, J., Jr \& Duine, J. A. (1984). Quinoprotein alcohol dehydrogenase from ethanolgrown Pseudomonas aeruginosa. Biochemical Journal 223, 921-924.

Groen, W., Van Kleef, M. A. G. \& Duine, J. A. (1986). Quinohaemoprotein alcohol dehydrogenase apoenzyme from Pseudomonas testosteroni. Biochemical Journal 234, 611-615.

HaAS, D. \& HollowaY, B. (1976). R-factor variant with enhanced sex factor activity in Pseudomonas aeruginosa. Molecular and General Genetics 144, 243251.

Harms, N., De Vries, G. E., MaUrer, K., HoogendJIK, J. \& Stouthamer, A. H. (1987). Isolation and nucleotide sequence of the methanol dehydrogenase structural gene from Paracoccus denitrificans. Journal of Bacteriology 169, 3969-3975.

HoHN, B. \& Collins, J. (1980). A small cosmid for efficient cloning of large DNA fragments. Gene 11, 291-298.

Hontebeyrie, M. \& Gasser, F. (1975). Comparative immunological relationships of two distinct sets of isofunctional dehydrogenases. International Journal of Systematic Bacteriology 25, 1-6.

HoOd, D., Dow, C. S. \& GREen, P. N. (1987). DNA :DNA hybridization studies on the pinkpigmented facultative methylotrophs. Journal of General Microbiology 133, 709-720.

JANVIER, M. \& GASSER, F. (1987). Purification and properties of methanol dehydrogenase from Methylophaga marina. Biochimie 69, 1169-1174.

KleCKNER, N., Roth, J. \& Botstein, D. (1977). Genetic engineering in vivo using translocatable drug-resistance elements. New methods in bacterial genetics. Journal of Molecular Biology 116, 125-139.

LAEMMLI, U. K. (1970). Cleavage of structural proteins during the assembly of the head of bacteriophage T4. Nature, London 227, 680-685.

Lobenstein-VerbeeK, C. J., Jongejan, J. A., Frank, J. \& Duine, J. A. (1984). Bovine serum amine oxidase: a mammalian enzyme having covalently bound $\mathrm{PQQ}$ as prosthetic group. FEBS Letters $\mathbf{1 7 0}$, 305-309.

Maclennan, D. G., Ousby, J. C., Vasey, R. B. \& CotTon, N. T. (1971). The influence of dissolved oxygen on Pseudomonas AM1 grown on methanol in continuous culture. Journal of General Microbiology 69, 395-404.

Maniatis, T., Fritsch, E. F. \& Sambrook, J. (1982). Molecular Cloning: a Laboratory Manual. Cold Spring Harbor, NY: Cold Spring Harbor Laboratory.
MARMUR, J. (1961). A procedure for the isolation of deoxyribonucleic acid from microorganisms. Journal of Molecular Biology 3, 208-218.

Mazodier, P., Giraud, E. \& Gasser, F. (1982) Tn5 dependent streptomycin resistance in Methylobacterium organophilum. FEMS Microbiology Letters 13, 27-30.

Mazodier, P., Giraud, E. \& Gasser, F. (1983). Genetic analysis of the streptomycin resistance encoded by Tn5. Molecular and General Genetics 192, $155-162$.

MilleR, J. H. (1972). Experiments in Molecular Genetics, p. 433. Cold Spring Harbor, NY: Cold Spring Harbor Laboratory.

MoORE, A. T., Nayudu, M. \& Holloway, B. W. (1983). Genetic mapping in Methylophilus methylotrophus AS1. Journal of General Microbiology 129, 785-799.

NUNN, D. N. \& LIDSTROM, M. E. (1986). Isolation and complementation analysis of 10 methanol oxidation mutant classes and identification of the methanol dehydrogenase structural gene of Methylobacterium sp. strain AM1. Journal of Bacteriology 166, 581-590.

O'KEEFE, D. T. \& ANTHONY, C. (1980). The two cyctochromes $c$ in the facultative methylotroph Pseudomonas AM1. Biochemical Journal 192, 411419.

Priefer, U. B., Simon, R. \& Pühler, A. (1985). Extension of the host range of Escherichia coli vectors by incorporation of RSF1010 replication and mobilization functions. Journal of Bacteriology 163, 324330.

Salisbury, S. A., Forrest, H. S., Cruse, W. B. T. \& KeNNARD, O. (1979). A novel coenzyme from bacterial primary alcohol dehydrogenases. Nature, London 280, 843-844.

Simon, R., Priefer, U. \& PÜHLer, A. (1983). A broad host range mobilisation system for in vivo genetic engineering: transposon mutagenesis in Gram negative bacteria. Biotechnology 1, 784-791.

Thomas, P. E., Ryan, D. \& Levin, W. (1976). An improved staining procedure for the detection of peroxidase activity of cytochrome $P .450$ on sodium dodecylsulfate polyacrylamide gels. Analytical Biochemistry 75, 168-176.

VAN DER MEER, R. A. \& DUINe, J. A. (1986). Covalently bound pyrroloquinoline quinone is the organic prosthetic group in human placental lysyl oxidase. Biochemical Journal 239, 789-791.

VAN DER MEer, R. A., Jongejan, J. A. \& Duine, J. A. (1987). Phenylhydrazine as probe for cofactor identification in amine oxidoreductases. Evidence for $P Q Q$ as the cofactor in methylamine dehydrogenase. FEBS Letters 221, 299-304. 